\title{
Influence of Online Shopping Buying Behaviour in Post Covid-19
}

\author{
P. Mari Selvam, A. Gomathi
}

\begin{abstract}
The corona virus which causes a highly infectious of Corona virus disease (COVID-19) that has affected more than 4 lakh people in around the world. Since it has been increased during the pandemic period online shopping usage, rural, urban and globally. In the current scenario many youngster's changing the attitude has purchased to online shopping because social distancing and self-quarantine efforts. Hence the online shopping promoters like Amazon, flip kart, Reliance digital and other agencies are for the time being too given the importance its available fulfilment and logistics facility to serve the basic needs such as household products, packaged food, health care, hygiene, personal safety and other high priority products. It is for the time being going to taking orders for lower-priority to high priority products. In this study to analyze the impact of online buying behaviour increased in after pandemic period.
\end{abstract}

Keywords: Buying Behaviour, Covid-19, Online Shopping,

\section{INTRODUCTION}

In the period of March 2020 situation is rapidly changing due to covid19. The people are safe to gather in a place. The same time Restaurants, bars, malls, theatres and gyms are closed due the pandemic. Meanwhile many offices are worked from home in the online mode. The peoples are struggling with basic needs of products for purchasing in the mode of direct. So that, the online shopping already was familiar one but in time of covid 19 very useful to buying a products with different varieties and also same the safe of door delivery. The survey of entitled "COVID-19 and way consumers use e-commerce and digital mode of buying behaviors. It covered Brazil, China, Germany, Italy, the Republic of Korea, Russian Federation, South Africa, Switzerland and Turkey. Following the pandemic, more than half of the survey's respondents now shop online more frequently and rely on the internet more for news, health-related information and digital entertainment.

Manuscript received on November 15, 2021.

Revised Manuscript received on November 23, 2021.

Manuscript published on November 30, 2021.

* Correspondence Author

Dr. P. Mari Selvam*, Assistant Professor, Department of Commerce, CMS College of Science and Commerce (Autonomous), Coimbatore (Tamil Nadu), India. Email: pmariselvam1986@gmail.com

Dr. A. Gomathi, Assistant Professor \& Head, Department of Psychology, CMS College of Science and Commerce (Autonomous), Coimbatore (Tamil Nadu), India. Email: gomathisuji@gmail.com

(C) The Authors. Published by Blue Eyes Intelligence Engineering and Sciences Publication (BEIESP). This is an open access article under the CC BY-NC-ND license (http://creativecommons.org/licenses/by-nc-nd/4.0/) Online Shopping Features. E-commerce", were examined the pandemic has changed the

\section{OBJECTIVES OF THE STUDY}

1. To analyse the socio economic status and impact of buying behaviours towards post covid19.

2. To identify the impact of buying behaviour during Post Covid-19 period in Coimbatore City.

\section{RESEARCH METHODOLOGY}

\section{A. Sources:}

The Primary data have been collected by sending the questionnaire through Google forms. The area of study selected from Coimbatore in Tamilnadu during the study period of October 2021.

\section{B. Sample Design}

Even though, the research designs are various methods, the present study followed the 'descriptive' research design. In the total population of Coimbatore city more than 10 lakhs people's for the collection of data only 400 respondents were selected randomly using lot method. The data has been collected among the different professionals in the Coimbatore city. The study was used basic tools of simple percentage method and chi-square test.

\section{LIMITATIONS OF THE STUDY}

1. The study is limited to exclusively Coimbatore city

2. The study was covered limited number of respondent with common job professionals.

Table 1 Socio-Economic Profile

\begin{tabular}{|c|c|c|c|c|}
\hline S.N & Sources & Variable & Frequency & Percentage \\
\hline \multirow[t]{3}{*}{1} & \multirow[t]{3}{*}{ Gender } & Male & 216 & 54.0 \\
\hline & & Female & 184 & 46.0 \\
\hline & & Total & 400 & 100.0 \\
\hline \multirow[t]{5}{*}{2} & \multirow[t]{5}{*}{ Occupation } & Agriculture & 57 & 14.2 \\
\hline & & Business & 146 & 36.5 \\
\hline & & Profession & 64 & 16.0 \\
\hline & & Employee & 133 & 33.2 \\
\hline & & Total & 400 & 100.0 \\
\hline \multirow[t]{6}{*}{3} & \multirow{6}{*}{$\begin{array}{l}\text { Annual } \\
\text { Income }\end{array}$} & Below 10,000 & 14 & 3.5 \\
\hline & & 10,000 to 50,000 & 21 & 5.2 \\
\hline & & 50,000 to $1,00,000$ & 219 & 54.8 \\
\hline & & $\begin{array}{l}100,000 \text { to } \\
5,00,000\end{array}$ & 117 & 29.2 \\
\hline & & $\begin{array}{l}5,00,000 \text { and } \\
\text { above }\end{array}$ & 29 & 7.2 \\
\hline & & Total & 400 & 100.0 \\
\hline \multirow[t]{4}{*}{4} & \multirow{4}{*}{$\begin{array}{l}\text { Impact of } \\
\text { Online } \\
\text { shopping } \\
\text { during }\end{array}$} & Strongly Agree & 222 & 55.5 \\
\hline & & Agree & 130 & 32.5 \\
\hline & & Moderate & 37 & 9.2 \\
\hline & & Disagree & 5 & 1.2 \\
\hline
\end{tabular}

\section{Published By:}




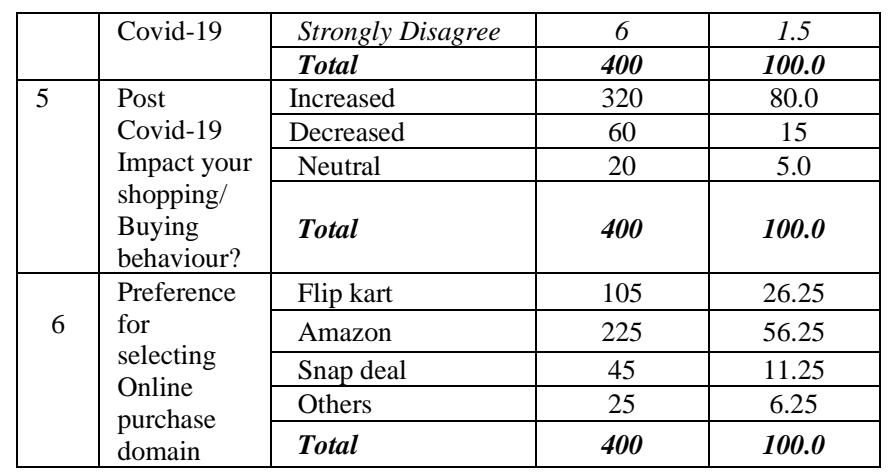

Source: Primary data

The above table explain the Socio-Economic status of impact of online shopping behaviour during Covid 19 lockdown period in Coimbatore city.

The majority of 216 respondents (54\%) are male category. The minimum numbers of respondents are female (46\%) category.

In this regard occupation of respondents are preference to online shopping in $14.2 \%$ of respondents are agriculture people; $36.5 \%$ of respondents are doing a business; $16.0 \%$ of respondents are common profession holders and $33.2 \%$ of respondents are basic employee are preference to buying behaviour in online shopping.

The above table explained that annual income with online buying behaviours towards during the pandemic period. 3.5\% of respondents are getting below l lakh annual income. 5.2 of respondents are up to 50,000 annual income generation people. The majority of respondents are buying online shopping in up to 1 laksh annual income. 29.2\% of respondents are up to 5 laksh income level of people are buying behaviour in online shopping in during the pandemic peiod.

The impact of online shopping during pandemic period $55.5 \%$ of people are strongly agree that buying the products through online. $32.5 \%$ of respondents are insisted that agree with buying the goods from online. $9.2 \%$ of respondents are moderate the buying culture with online. The minimum number of $1.2 \%$ and $1.5 \%$ of respondents are strongly disagree with purchase the online shopping.

\section{Table 2 Occupation and Impact of Online shopping} during Covid-19

\begin{tabular}{|l|c|c|c|c|c|c|}
\hline \multirow{3}{*}{ Occupation } & & \multicolumn{4}{|c|}{ Impact of Online Shopping } & \multirow{2}{*}{ Total } \\
\cline { 3 - 7 } & & $\begin{array}{c}\text { Strongly } \\
\text { Agree }\end{array}$ & Agree & Neutral & $\begin{array}{c}\text { Strongly } \\
\text { disagree }\end{array}$ & \\
\hline \multirow{3}{*}{ Agriculture } & Count & 38 & 85 & 65 & 35 & 223 \\
\cline { 2 - 7 } & $\%$ & $9.50 \%$ & $21.20 \%$ & $16.20 \%$ & $8.80 \%$ & $55.80 \%$ \\
\hline \multirow{3}{*}{ Business } & Count & 18 & 45 & 47 & 25 & 135 \\
\cline { 2 - 7 } & $\%$ & $4.50 \%$ & $11.20 \%$ & $11.80 \%$ & $6.20 \%$ & $33.80 \%$ \\
\hline \multirow{3}{*}{ Employee } & Count & 1 & 14 & 18 & 4 & 37 \\
\cline { 2 - 7 } & $\%$ & $0.20 \%$ & $3.50 \%$ & $4.50 \%$ & $1.00 \%$ & $9.20 \%$ \\
\hline \multirow{3}{*}{ Profession } & Count & 0 & 2 & 3 & 0 & 5 \\
\cline { 2 - 7 } & $\%$ & $0.00 \%$ & $0.50 \%$ & $0.80 \%$ & $0.00 \%$ & $1.20 \%$ \\
\hline \multirow{2}{*}{ Total } & Count & $\mathbf{5 7}$ & $\mathbf{1 4 6}$ & $\mathbf{1 3 3}$ & $\mathbf{6 4}$ & $\mathbf{4 0 0}$ \\
\cline { 2 - 7 } & Total & $\mathbf{1 4 . 2 0 \%}$ & $\mathbf{3 6 . 5 0} \%$ & $\mathbf{3 3 . 2 0} \%$ & $\mathbf{1 6 . 0 0 \%}$ & $\mathbf{1 0 0 . 0 0 \%}$ \\
\hline
\end{tabular}

\section{Source: Primary data}

The above table indicates that Occupation and Impact of online shopping during covid19. 55.8\% of respondents are strongly agreed with online shopping during the period of pandemic. 33.8\% of respondents are agree with online buying behaviour in covid 19 period. 9.2\% of respondents are suggested that natural with both online and off line shopping. Minimum $1.2 \%$ of respondents are strongly disagree with there is no impact created in online shopping during the pandemic period.

Ho: There is no significance difference between Occupation and Impact of Online shopping during Covid-19

\begin{tabular}{|l|c|c|c|}
\hline \multicolumn{4}{|c|}{ Chi-Square Tests } \\
\hline & Value & $\mathrm{df}$ & $\begin{array}{c}\text { Asymp. Sig. } \\
\text { (2-sided) }\end{array}$ \\
\hline $\begin{array}{l}\text { Pearson } \\
\text { Chi-Square }\end{array}$ & $12.952^{\mathrm{a}}$ & 9 & 0.145 \\
\hline $\begin{array}{l}\text { Likelihood } \\
\text { Ratio }\end{array}$ & 15.72 & 9 & 0.063 \\
\hline $\begin{array}{l}\text { N of Valid } \\
\text { Cases }\end{array}$ & 400 & & \\
\hline \multicolumn{2}{|c|}{ a. 4 cells (25.0\%) have expected count less than 5. The minimum } \\
expected count is .71.
\end{tabular}

The value of chi-square test (12.952) at high p-value of (0.165) indicates that the null hypothesis rejected at 5 percent level of significance. Hence it may be concluded that there is a significant relationship between occupation and impact of online shopping during the pandemic period.

Table 3 Annual Income and Impact of Online shopping during Covid-19

\begin{tabular}{|c|c|c|c|c|c|c|}
\hline \multirow{2}{*}{$\begin{array}{l}\text { Annual } \\
\text { Income }\end{array}$} & & \multicolumn{4}{|c|}{ Impact of Online Shopping } & \multirow[b]{2}{*}{ Total } \\
\hline & & $\begin{array}{c}\begin{array}{c}\text { Strongly } \\
\text { Agree }\end{array} \\
\end{array}$ & Agree & Neutral & $\begin{array}{l}\begin{array}{l}\text { Strongly } \\
\text { disagree }\end{array} \\
\end{array}$ & \\
\hline \multirow{2}{*}{$\begin{array}{l}\text { Below } \\
10,000\end{array}$} & Count & 11 & 3 & 0 & 0 & 14 \\
\hline & $\%$ & $2.80 \%$ & $0.80 \%$ & $0.00 \%$ & $0.00 \%$ & $3.50 \%$ \\
\hline \multirow{2}{*}{$\begin{array}{l}10,000 \\
\text { to } \\
50,000\end{array}$} & Count & 7 & 6 & 1 & 0 & 14 \\
\hline & $\%$ & $1.80 \%$ & $1.50 \%$ & $0.20 \%$ & $0.00 \%$ & $3.50 \%$ \\
\hline \multirow{2}{*}{$\begin{array}{l}50,000 \\
\text { to } \\
1,00,000\end{array}$} & Count & 29 & 17 & 3 & 0 & 49 \\
\hline & $\%$ & $7.20 \%$ & $4.20 \%$ & $0.80 \%$ & $0.00 \%$ & $12.20 \%$ \\
\hline \multirow{2}{*}{$\begin{array}{l}100,000 \\
\text { to } \\
5,00,000\end{array}$} & Count & 28 & 13 & 5 & 3 & 49 \\
\hline & $\%$ & $7.00 \%$ & $3.20 \%$ & $1.20 \%$ & $0.80 \%$ & $12.20 \%$ \\
\hline \multirow{2}{*}{$\begin{array}{l}5,00,000 \\
\text { and } \\
\text { above }\end{array}$} & Count & 149 & 95 & 28 & 2 & 274 \\
\hline & $\%$ & $37.20 \%$ & $23.80 \%$ & $7.00 \%$ & $0.50 \%$ & $68.50 \%$ \\
\hline \multirow{2}{*}{ Total } & Count & 224 & 134 & 37 & 5 & 400 \\
\hline & Total & $56.00 \%$ & $33.50 \%$ & $9.20 \%$ & $1.20 \%$ & $100.00 \%$ \\
\hline
\end{tabular}

Source: Primary data

The above table indicates that annual income and impact of online shopping during the pandemic period. $3.5 \%$ of respondents are low level of income people's up to annual income 50,000, as suggested very minimum of buying behaviour towards online shopping due to income once the reason. $12.2 \%$ of respondents are up to5 lakh annual income, as in the category average income generation people are buying the products in the mode online shopping. The majority of people are above 5 lakh annual income generation people are preference to $68.5 \%$ of online buying behaviour towards in the period of pandemic. Ho: There is no significance difference between Annual Income and Impact of Online shopping during Covid-19

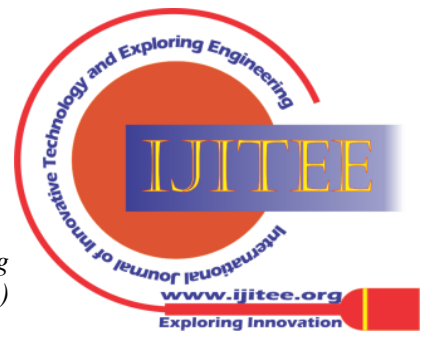




\begin{tabular}{|l|c|c|c|}
\hline \multicolumn{4}{|c|}{ Chi-Square Tests } \\
\hline & Value & df & $\begin{array}{c}\text { Asymp. Sig. } \\
\text { (2-sided) }\end{array}$ \\
\hline Pearson Chi-Square & $16.479^{\mathrm{a}}$ & 12 & 0.17 \\
\hline Likelihood Ratio & 14.333 & 12 & 0.28 \\
\hline $\begin{array}{l}\text { Linear-by-Linear } \\
\text { Association }\end{array}$ & 2.257 & 1 & 0.133 \\
\hline N of Valid Cases & 400 & & \\
\hline $\begin{array}{l}\text { a. 11 cells (55.0\%) have expected count less than 5. The minimum } \\
\text { expected count is .18. }\end{array}$ \\
\hline
\end{tabular}

The value of chi-square test (16.479a) at high p-value of (.710) indicates that the null hypothesis rejected at 5 percent level of significance. Hence it may be concluded that there is a significant relationship between Annual Income and Impact of Online shopping during Covid-19.

\section{CONCLUSION}

The above study revealed that the impact of online shopping during the period of post covid19 in respondents are strongly agreed with increased the sale and buying behaviour changed in online mode because the safety is first. So that many of respondents in the post pandemic period are preference to buying the products through online especially Amazon and flip kart and other online services. The maximum of respondents are above 5 laksh income generation people are mostly preference to online shopping due to various type of work and time schedule purposes. The study was concluding that post covid19 period increased the sale of online shopping with help of Indian economy.

\section{REFERENCES}

1. Akhtar, N.; Nadeem Akhtar, M.; Usman, M.; Ali, M.; Iqbal Siddiqi, U. "COVID-19 restrictions and consumers' psychological reactance toward oine shopping freedom restoration," Serv. Ind. J., 2020, 40, 891-913.

2. Baker, S.R.; Bloom, N.; Davis, S.J.; Kost, K.; Sammon, M.; Viratyosin, T. " The Unprecedented Stock Market Reaction to COVID-19, " Rev. Asset Pricing Stud., 2020, 10, 742-758.

3. Cherry, J.D. "The chronology of the 2002-2003 SARS mini pandemic," Paediatr. Respir. Rev. 2020, 5, 262-269.

4. Kirk, C.P.; Rifkin, L.S. "I'll trade you diamonds for toilet paper: Consumer reacting, coping and adapting behaviours in the COVID-19 pandemic," J. Bus. Res. 2020, 117, 124-131.

5. Laato, S.; Islam, A.K.M.N.; Farooq, A.; Dhir, A. "Unusual purchasing behavior during the early stages of the COVID-19 pandemic: The stimulus-organism-response approach,” J. Ret. Cons. Serv. 2020, 57, 102224.

6. Mason, A.; Narcum, J.; Mason, K. "Changes in consumer decision-making resulting from the COVID-19 pandemic," J. Cust. Behav.2020, 22

7. Pantano, E.; Pizzi, G. Scarpi, D.; Dennis, C. "Competing during a pandemic? Retailers' ups and downs during the COVID-19 outbreak," J. Bus. Res. 2020, 116, 209-213.

8. Sheth, J. "Impact of Covid-19 on consumer behavior: Will the old habits return or die?" J. Bus. Res. 2020, 117, 280-283.

\section{AUTHORS PROFILE}

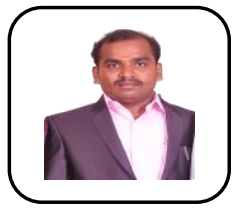

Dr. P. Mari Selvam is an Assistant Professor in the PG and Research Department of Commerce, CMS College of Science and Commerce (Autonomous), Coimbatore, Tamil Nadu. He obtained his UG degree from the Mano College, Puliangudi affiliated to Mamaonmaniam Sundaranar University, Tirunelveli. He finished M.Com in 2009 from the Department of Commerce, Rajus' College, Rajapalayam affiliated to Madurai Kamaraj University. In the year 2010, he obtained M.Phil from the Mamaonmaniam Sundaranar University, Tirunelveli and successfully completed Ph.D from Bharathidasan University, Tiruchirappalli. He also obtained MBA from Alagappa University, Karaikudi. Apart from that, he also secured certain diplomas like PGDCA from the reputed institution and also he has passed SET in Commerce. He has teaching experience for over 10 years and produced 1 M.Phil Candidate, guiding 4 Ph.D scholars. He is specialized in International Accounting concept and Entrepreneurship Development. He published more than 50 research articles in National and International journal and presented about 50 papers in National and International seminars. He has worked as Research Officer in ICSSR Major Research Project during 2011-2014. He is a Membership of Professional Bodies like Life Member: Indian Academic Researchers Association, Senior Member on International Society for Research and Development, London, Life Member on Indian Accounting Association, Trichy Chapter, Executive Member of Indian Accounting Association, Tiruchirappalli branch, Member in National Teacher Congress Foundation, Pune, Editor in Personal Financial Management, Text \& Cases, Editorial Advisory Board Member on SELP Journal of Science, Editorial member on Demonetization and Effects on Indian Financial System. He received Ambedkar Social Service Award, Best Social Scientist Award, Best Faculty Award, and Best Researcher Award from various reputed institutions.

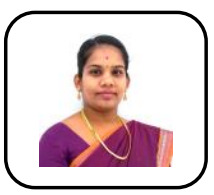

Dr. A. Gomathi, Head and Assistant professor, Department of Psychology, CMS College of Science and Commerce, Coimbatore. She has 8 years teaching experience. She published more than 10 research articles in National and International journals and presented about 20 papers in National and International conferences. She is a member in Indian School Psychology Association (InSPA), Life Member in Indian Academic Researchers Association, Life Member in Tamilnadu Psychology Association, Member in Coimbatore Productivity Council and life member in International Society for Research and Development. She has honored with the award of Best Research Scholar Award and Best Faculty Award. She provides counselling and guidance for Students. She is guiding M .A Psychology students from Indira Gandhi National Open University (IGNOU). Furthermore, Dr. A. Gomathi is dedicated, resourceful and a goal-driven professional educator with a solid commitment to the social and academic growth and development of every student. She is highly motivated and enthusiastic who wants all her students to be successful. She is committed to professional ethics, standards and community service. She has proven abilities in problem solving, people management and motivation. She is accustomed to working in a multicultural environment that emphasizes inclusion. She strives to build student self-esteem and encourage understanding of cultural diversity, gender differences and physical limitations. She has good verbal and written communication skills, leadership skills and time management, conflict resolution skills and up-to-date teaching methods all that are important for being a Professional Educator .

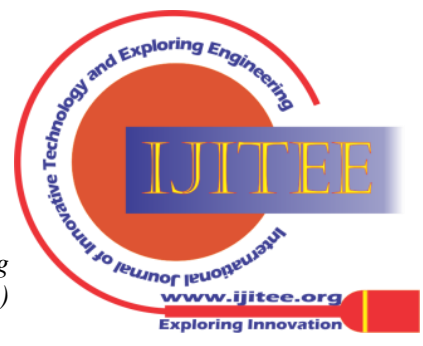

